\title{
Construction and characterisation of a recombinant fowlpox virus that expresses the human papilloma virus L1 protein
}

\author{
Carlo Zanotto $^{1 \dagger}$, Eleana Pozzi ${ }^{1 \dagger}$, Sole Pacchioni ${ }^{1}$, Massimiliano Bissa ${ }^{1}$, Carlo De Giuli Morghen ${ }^{1,3}$ and \\ Antonia Radaelli ${ }^{2,3 *}$
}

\begin{abstract}
Background: Human papilloma virus (HPV)-16 is the most prevalent high-risk mucosal genotype. Virus-like-particle (VLP)-based immunogens developed recently have proven to be successful as prophylactic HPV vaccines, but are still too expensive for developing countries. Although vaccinia viruses expressing the HPV-16 L1 protein (HPV-L1) have been studied, fowlpox-based recombinants represent efficient and safer vectors for immunocompromised hosts due to their ability to elicit a complete immune response and their natural host-range restriction to avian species.
\end{abstract}

Methods: A new fowlpox virus recombinant encoding HPV-L1 ( $\left.F P_{L 1}\right)$ was engineered and evaluated for the correct expression of HPV-L1 in vitro, using RT-PCR, immunoprecipitation, Western blotting, electron microscopy, immunofluorescence, and real-time PCR assays.

Results: The FP $P_{\mathrm{L} 1}$ recombinant correctly expresses HPV-L1 in mammalian cells, which are non-permissive for the replication of this vector.

Conclusion: This $\mathrm{FP}_{\mathrm{L} 1}$ recombinant represents an appropriate immunogen for expression of HPV-L1 in human cells. The final aim is to develop a safe, immunogenic, and less expensive prophylactic vaccine against HPV.

\section{Background}

Cervical cancer caused by human papilloma virus (HPV) is the second leading cause of malignancies in women worldwide, and the first in developing countries. Persistent infection with one of the approximately fifteen highrisk oncogenic HPV types can cause the onset of cervical intraepithelial neoplasia and progression to invasive cervical cancer [1]. Approximately 500,000 cases are diagnosed every year, resulting in 274,000 deaths $[2,3]$.

The absence of specific antiviral drugs has stimulated the search for prophylactic vaccines against HPV-16 and HPV-18, which are the HPV genotypes that are most commonly associated with the disease. In particular, HPV-16 is by far the most prevalent high-risk mucosal genotype, and, as it is present in around $50 \%$ of all

\footnotetext{
* Correspondence: antonia.radaelli@unimi.it

† Contributed equally

${ }^{2}$ Department of Pharmacological Sciences, University of Milan, 20133 Milan, Italy

Full list of author information is available at the end of the article
}

cervical cancers $[1,4,5]$, it has been the focus of many recent vaccine developments.

Although therapeutic vaccines are of high priority for the control of progression to neoplasia in subjects who are already infected, prophylactic vaccines are important to limit the diffusion of infection. They are therefore the best choice for intervention against HPVs, as they can neutralise the incoming virus and prevent disease progression.

The preparation of a new vaccine has been hampered for a long time because of the restricted host range of the virus and its selective tropism for differentiated squamous epithelium, which makes its growth in cell culture difficult. Expression of the L1 major capsid protein of HPV-16 (HPV-L1) in eucaryotic cells results in the formation of empty virus capsids (virus-like particles; VLPs) [6] which are very similar to native virions, show icosahedral symmetry, and can enter cells like infectious virions. In particular, VLPs have proven to be 
successful as prophylactic bivalent [7] and quadrivalent [8] HPV vaccines in women, by eliciting virus-neutralising antibodies in large randomized controlled clinical trials [9-11]. They have also shown higher immunogenicity than capsomers, although similar titres of neutralising antibodies can be induced using strong immune adjuvants [12]. VLPs enter the MHC-II processing pathway and they can induce a CD4-restricted T-cell response, which is important for both robust antibody and memory responses, as has been summarized in different reviews [13-15]. Different studies also suggest that VLPs can also deliver foreign protein to the MHC-I pathway to elicit cytotoxic T-cell responses [16-18]. However, VLPs are still too expensive for less-developed countries, they are not thermostable, and they need to be delivered by injection.

Immunisation with vaccinia virus recombinants expressing HPV genes or other viral antigens has been demonstrated to be a good candidate for stimulation of the immune system [19]. However, their use has raised safety concerns due to severe collateral effects in immunocompromised individuals [20]. VLPs have also been produced in plant in various studies [21,22], and also as a chimeric L1 fused with cytotoxic E6 epitopes [23].

The avipox viruses, and the fowlpox virus (FP) in particular, represent alternative vectors due to their natural hostrange restriction to avian species $[24,25]$, to their correct expression of transgenes in mammalian cells, and to their elicitation of a long-lasting immune response in the vaccinated hosts [26,27]. Compared to VLP-based HPV vaccines that are produced by yeast or baculovirus, and that mainly induce humoral responses, FP-based recombinants elicit a complete and more effective immunity. Moreover, as these FP-based recombinants do not immunologically cross-react with vaccinia viruses, they can be administered to previously vaccinia-virus-experienced individuals, thus circumventing neutralisation by vector-generated immunity [28]. These viruses have thus acquired an important role in the development of novel vaccines against human diseases, as they may represent safer vectors than wild-type or attenuated vaccinia viruses $[24,29]$.

In the present study, a new FP recombinant encoding HPV-L1 $\left(\mathrm{FP}_{\mathrm{L} 1}\right)$ was engineered and evaluated for its correct expression in vitro, with the final aim of developing a prophylactic vaccine. This recombinant should express foreign genes intracellularly and allow cross-presentation of the antigen in association with both MHC class I and II complexes, thus eliciting a complete humoral and cellular protective immunity.

\section{Methods}

\section{Cells}

CaSki cells carrying multiple copies of integrated HPV16 DNA, green monkey kidney (Vero) cells, and MRC-5 human lung fibroblasts were grown in Dulbecco's modified Eagle's medium (DMEM) supplemented with 10\% heat-inactivated calf serum (Gibco/Invitrogen, Carlsbad, CA, USA), $100 \mathrm{U} / \mathrm{ml}$ penicillin and $100 \mu \mathrm{g} / \mathrm{ml}$ streptomycin $(\mathrm{P} / \mathrm{S})$. Specific-pathogen-free primary chick embryo fibroblasts (CEFs) were grown in DMEM with $5 \%$ heat-inactivated calf serum, $5 \%$ tryptose phosphate broth (TPB; Difco Laboratories, Detroit, MI, USA), and $\mathrm{P} / \mathrm{S}$.

\section{Production of HPV-16 L1}

The pQE30 expression plasmid (Qiagen, Valencia, CA, USA) engineered to contain the L1 gene of HPV-16 [30] (pQE30-L1-NLS-His) was kindly supplied by C. Giorgi (Istituto Superiore di Sanità, Rome, Italy). After its cloning into JM109 bacterial cells, this engineered plasmid was used for the production of the RGS/L1/His-tagged protein, according to the manufacturer instructions (Qiagen), with minor modifications. Briefly, JM109/ pQE30-L1-NLS-His bacterial cells were lysed in phosphate lysis buffer $(300 \mathrm{mM} \mathrm{NaCl}, 1 \%$ Triton X-100, $\mathrm{pH}$ 8 , prepared in buffer A: $10 \mathrm{mM}$ Tris, $100 \mathrm{mM}$ $\mathrm{Na}_{2} \mathrm{HPO}_{4}, 6 \mathrm{M}$ guanidine- $\mathrm{HCl}, \mathrm{pH}$ 8). After clarification for $30 \mathrm{~min}$ at $17,000 \times g$ at $4^{\circ} \mathrm{C}$, the supernatant containing the HPV-L1 preparation was supplemented with $1 \%$ Triton X-100/20 mM imidazole, $\mathrm{pH} \mathrm{8,} \mathrm{in} \mathrm{buffer} \mathrm{A.}$ This was then incubated with Ni-NTA agarose resin (Qiagen) for $30 \mathrm{~min}$ at room temperature. After washing once with $1 \%$ Triton X-100 in buffer A, twice with buffer A, and multiple times with buffer C (100 mM $\mathrm{Na}_{2} \mathrm{HPO}_{4}, 10 \mathrm{mM}$ Tris, $8 \mathrm{M}$ Urea, $\mathrm{pH}$ 6.3) up to a final optical density of 0.013 , the protein was eluted into different fractions with $1 \mathrm{M}$ imidazole, $\mathrm{pH}$ 8. After their analysis by $15 \%$ PAGE, the fractions enriched in the recombinant HPV-L1 were pooled. The HPV-L1 was dialysed overnight at $4^{\circ} \mathrm{C}$ using a slide-A-lyser cassette (10 kDa MW cut-off, Pierce, Rockford, IL, USA), and soaked in dialysis buffer $(25 \mathrm{mM}$ Tris- $\mathrm{HCl}, 100 \mathrm{mM}$ $\mathrm{NaCl})$. The protein was quantified, stored at $-80^{\circ} \mathrm{C}$ and used as a control in the Western blotting.

\section{Construction of the recombination plasmid}

The L1 gene of HPV-16 was amplified from the pUF3/ L1 plasmid that contained the humanised HPV-L1 gene sequence (1,518 bp; accession number: AJ313179) [31] kindly supplied by M. Mueller (German Cancer Research Center, Heidelberg, Germany). This was inserted into the multicloning site (MCS) downstream of the early/late VVH6 promoter [32,33] of the pFPMCS-GFP plasmid. The enhanced GFP (green fluorescent protein) gene derived from pEGFP-N1 (BD Biosciences Clontech Laboratories, Inc., Mountain View, CA, USA) is therefore located downstream of the L1 gene, but in the reverse orientation and under the 
control of the synthetic SP promoter [34] (a gift from A. Siccardi, HSR, Milan, Italy). The L1 and GFP genes are both inside the two arms of the 3- $\beta$-hydroxysteroid dehydrogenase 5-delta 4 isomerase gene (DH) fowlpox gene, used for site-specific in-vitro recombination [35]. The DNA sequence encoding the complete L1 region of HPV-16 was amplified using the V178 (5'-GCC-GCGCCC-GGG-AAG-CTT-ATG-AGC-CTG-TGG-CTGCCC-AGC-GAG-3') and V179 (5'-GCC-GCG-GTCGAC-AAG-CTT-TCA-CAG-CTT-CCT-CTT-CTT-CC3 ') primers. The amplification was carried out starting from $250 \mathrm{ng}$ DNA in a final volume of $50 \mu \mathrm{l}$, in a mixture containing $1 \mu \mathrm{M}$ of each primer, $200 \mu \mathrm{M}$ of each $\mathrm{dNTP}, 3 \mu \mathrm{M} \mathrm{MgCl}$, $2.0 \mathrm{mM} \mathrm{MgSO}_{4}$, and $0.025 \mathrm{U} / \mu \mathrm{l}$ Pwo DNA polymerase (Boehringer Mannheim, Indianapolis, IN, USA). The PCR conditions were: $95^{\circ} \mathrm{C}$ for 45 s, followed by 30 cycles at $95^{\circ} \mathrm{C}$ for $30 \mathrm{~s}, 70^{\circ} \mathrm{C}$ for $30 \mathrm{~s}$, $72^{\circ} \mathrm{C}$ for $80 \mathrm{~s}$, and $72^{\circ} \mathrm{C}$ for 7 min (PTC-200 thermocycler; MJ Research, Waltham, MA, USA). The HPV-L1 gene was first cloned into the pCR-BluntII-TOPO plasmid (Invitrogen, Carlsbad, CA, USA), which allows the insertion of blunt-ended sequences. The pCR-BluntII$\mathrm{TOPO} / \mathrm{L} 1$ was then cut out with HindIII (Fermentas, M-Medical, Milan, Italy) and ligated into the pFP recombinant vector, which had been previously linearised with HindIII for $1 \mathrm{~h}$ at $37^{\circ} \mathrm{C}$. Ligation was carried out overnight at $16^{\circ} \mathrm{C}$ in $10 \mu \mathrm{l}$, using $1 \mathrm{U}$ T4 DNA ligase (USB, Amersham-Pharmacia Biotech AB, Uppsala, Sweden) and $100 \mathrm{ng}$ of the insert at an insert:vector molar ratio of 3:1. After transformation of supercompetent ECL bacterial cells, the colonies were screened by amplifying the HPV-L1 gene, and further analysed by digestion with the NruI/KpnI and HindIII/EcoRI restriction enzymes, to verify the correct orientation of the insert. The cloned recombinant plasmid was purified (Qiagen, Hilden, Germany) and sequenced (Genenco, MMedical, Milan, Italy) to exclude any possible mutation arising from PCR amplification. This cloned recombinant plasmid is henceforth referred to as $\mathrm{pFP}_{\mathrm{L} 1}(9,726 \mathrm{bp})$.

In-vitro recombination to generate the $\mathrm{FP}_{\mathrm{L} 1}$ recombinant The $\mathrm{FP}_{\mathrm{L} 1}$ recombinant was obtained by in-vitro recombination in specific-pathogen-free primary CEFs, as described previously $[35,36]$, using the wild-type FP virus (FPwt) and $\mathrm{pFP}_{\mathrm{L} 1}$. Briefly, the CEFs were infected with 0.5 PFU/cell FPwt in DMEM containing 2\% foetal calf serum, and, after a 4 -h incubation at $37^{\circ} \mathrm{C}$, they were transfected by calcium phosphate precipitation using $125 \mu \mathrm{g} \mathrm{pFP} \mathrm{L}_{1}$ DNA in $1 \mathrm{ml}$ of a mixture containing $125 \mu \mathrm{M} \mathrm{CaCl}_{2}$ in $40 \mathrm{mM}$ HEBS, $\mathrm{pH} \mathrm{7,300} \mathrm{mM}$ $\mathrm{NaCl}, 1.4 \mathrm{mM} \mathrm{Na}_{2} \mathrm{HPO}_{4}, 10 \mathrm{mM} \mathrm{KCl}$, and $12 \mathrm{mM}$ dextrose. Two days after the infection, the FP virus was released from the cells by three freeze-thaw cycles and used for further infection and selection of the recombinants. Recombinant plaques were identified by autoradiography after hybridisation with a $\left[{ }^{32} \mathrm{P}\right]$-labelled HPV-L1 probe, and then subjected to multiple cycles of plaque purification. One clone was selected for correct and highest expression of the HPV-L1 gene by Western blotting. The $\mathrm{FP}_{\mathrm{L} 1}$ recombinant was amplified in CEFs and purified on a sucrose gradient, as described previously [33].

\section{mRNA transcript expression in replication-restrictive Vero cells}

The expression of the HPV-L1 gene was first determined by RT-PCR, after infecting Vero cells with 5 PFU of $\mathrm{FP}_{\mathrm{L} 1}$ recombinant. The experiments were performed in duplicate. RNA was extracted 1 day post-infection (p. i.) and every 3 days for 21 days, using Trizol LS (Gibco) to determine the level of HPV-L1 transcripts in nonpermissive mammalian cells. The mRNAs from all of the samples were treated with $10 \mathrm{U}$ RNase-free DNase I (Roche Diagnostics, Indianapolis, IN, USA) for $4 \mathrm{~h}$ at $37^{\circ} \mathrm{C}$, to eliminate any cellular or viral DNA, then precipitated with $100 \%$ ethanol in the presence of $100 \mathrm{mM}$ $\mathrm{Na}$ acetate. After washing in $75 \%$ ethanol and resuspension in diethylpyrocarbonate-treated water, RT-PCR was carried out using the Access RT-PCR System kit (Promega, Madison, WI, USA). Briefly, 50 ng RNA from each sample was used in a final volume of $20 \mu \mathrm{l}$, in the presence of $1 \mathrm{mM}$ of each primer, $200 \mathrm{mM}$ of each dNTP, $0.1 \mathrm{U} / \mathrm{ml}$ Tfl DNA polymerase, $0.1 \mathrm{U} / \mathrm{ml}$ AMV reverse transcriptase (AMV-RT), and $2.0 \mathrm{mM} \mathrm{MgSO}_{4}$. Control samples without AMV-RT were also prepared. The presence of the HPV-L1 transcript was verified using the V191 (5'-CGA-CAC-CAG-CTT-CTA-CAA-C3') and V190 (5'-TGT-TGA-ACA-GGT-GCC-TC-3') primers. Human $\beta$-actin was also amplified as an internal control, using the V84 (5'-CTG-ACT-ACC-TCATGA-AGA-TCC-T-3') and V85 (5'-GCT-GAT-CCACAT-CTG-CTG-GAA-3') primers, and a band of 518 bp was obtained. Mock-infected Vero cells were used as a negative control. The reverse transcriptase reaction was carried out at $48^{\circ} \mathrm{C}$ for $45 \mathrm{~min}$, followed by $2 \mathrm{~min}$ at $94^{\circ} \mathrm{C}$. PCR amplification was performed for 35 cycles at $94^{\circ} \mathrm{C}$ for $30 \mathrm{~s}, 60^{\circ} \mathrm{C}$ for $30 \mathrm{~s}$, and $68^{\circ} \mathrm{C}$ for $1 \mathrm{~min}$, followed by a final incubation at $68^{\circ} \mathrm{C}$ for $7 \mathrm{~min}$. For human $\beta$-actin, the RNA (50 ng) amplification was carried out as described above, but with $1 \mathrm{mM} \mathrm{MgSO}_{4}$. The thermal profile was at $48^{\circ} \mathrm{C}$ for $45 \mathrm{~min}$ followed by $94^{\circ} \mathrm{C}$ for $2 \mathrm{~min}$ and 40 cycles at $94^{\circ} \mathrm{C}$ for $30 \mathrm{~s}, 58^{\circ} \mathrm{C}$ for $30 \mathrm{~s}, 68^{\circ} \mathrm{C}$ for $1 \mathrm{~min}$, and with a final extension of $68^{\circ} \mathrm{C}$ for $7 \mathrm{~min}$. The PCR products were run on 1\% agarose gels and the gel images were acquired using a Speedlight Platinum apparatus (Lightools Research, Encinitas, CA, USA). The RT-PCR products were quantified using the ImageJ software [37]. 


\section{Radioimmunoprecipitation analysis}

The cells were infected with $5 \mathrm{PFU} / \mathrm{ml}$ in DME methionine-, cystine-, and L-glutamine-free medium (DMEM met $^{-}$, cys ${ }^{-}$, glut ${ }^{-}$MP Biomedicals Inc, DBA, Milan, Italy). After $2 \mathrm{~h}, 20 \mu \mathrm{Ci} / \mathrm{ml}\left[{ }^{35} \mathrm{~S}\right]$-methionine and $\left[{ }^{35} \mathrm{~S}\right]$-cysteine were added, using the same medium supplemented with $2 \%$ dialysed foetal bovine serum (Gibco). Sixteen hours p.i., the cells in $2 \mathrm{ml}$ of medium were harvested by resuspending them in $1 \mathrm{ml}$ lysis buffer $(150 \mathrm{mM} \mathrm{NaCl}$, $1 \mathrm{mM}$ EDTA, $10 \mathrm{mM}$ Tris- $\mathrm{HCl}, \mathrm{pH} 7.4,0.2 \mathrm{mg} / \mathrm{ml}$ PMSF, 1\% NP40, 0.01\% sodium azide) and $0.6 \mathrm{TIU}$ aprotinin (Sigma, St Louis, MO, USA) per Petri dish, with scraping into microcentrifuge tubes (Eppendorf, Milan, Italy). The lysate was clarified by centrifugation at $9,000 \times g$ for $20 \mathrm{~min}$ at $4^{\circ} \mathrm{C}$. Immunoprecipitation was performed either with $2 \mu \mathrm{l}$ anti-HPV-L1 preadsorbed polyclonal mouse serum (C. Giorgi) or with a monoclonal antibody (CamVir-1; BD Biosciences, San Diego, CA, USA). Proteins were resolved using 12.5\% SDS-PAGE, and fluorographed.

\section{Western blotting}

To determine whether HPV-L1 was expressed correctly by the $\mathrm{FP}_{\mathrm{L} 1}$ recombinant, Vero cells were infected with $5 \mathrm{PFU} /$ cell $\mathrm{FP}_{\mathrm{L} 1}$ recombinant and examined by Western blotting. The pelleted cells were lysed in sample buffer (50 mM Tris, pH 6.8, 10\% SDS, 1.5\% dithiothreitol, $0.05 \%$ bromophenol blue), boiled for $5 \mathrm{~min}$, and loaded onto polyacrylamide gels. After running through a $4 \%$ stacking gel for $1 \mathrm{~h}$ at $20 \mathrm{~mA}$ and through a $15 \%$ running gel for $1.5 \mathrm{~h}$ at $40 \mathrm{~mA}$, the proteins were transferred onto $0.2 \mu \mathrm{m}$ nitrocellulose membranes (Bio-Rad Laboratories, Milan, Italy) for $1 \mathrm{~h}$ at $100 \mathrm{~V}$ in cold transfer buffer (150 mM glycine, $20 \mathrm{mM}$ Tris, 20\% methanol) using a transblot apparatus (Bio-Rad). Soon after the protein transfer to the nitrocellulose, the positions of protein markers (Precision Plus Protein ${ }^{\mathrm{TM}}$ All blue standards, Bio-Rad) $(5 \mu \mathrm{l} / \mathrm{gel})$ were marked on the nitrocellulose. The nitrocellulose membranes were incubated for $30 \mathrm{~min}$ in $0.5 \%$ glutaraldehyde (Polysciences, Inc., Warrington, PA, USA), washed in $\mathrm{H}_{2} \mathrm{O}$, and incubated for $1 \mathrm{~h}$ with $5 \%$ skimmed milk (Merck, West Point, PA, USA) in $\mathrm{Ca}^{2+}$-free and $\mathrm{Mg}^{2+}$-free phosphatebuffered saline $\left(\mathrm{PBS}^{-}\right)$. After three rinses in wash buffer (20\% Tween in $\mathrm{PBS}^{-}$), the nitrocellulose membrane was incubated overnight at $4{ }^{\circ} \mathrm{C}$ with a 1:5,000 dilution of the specific anti-HPV-L1 CamVir-1 antibody (BD Biosciences). The washing was followed by a 1-h incubation with a goat anti-mouse horseradish peroxidase antibody (1:10,000 dilution; Dako Cytomation), and 2-h washes, before the HPV-L1 was revealed using the ECL system (GE Healthcare, Buckinghamshire, UK). The densitometric analysis of the Western blotting bands of the L1 protein was performed using the ImageJ software [37].

\section{Immunofluorescence}

The expression of HPV-L1 was also examined by immunofluorescence. Vero cells were seeded at a density of 5 $\times 10^{5} / 35-\mathrm{mm}^{2}$ dish on sterile glass coverslips, before infection with $5 \mathrm{PFU} /$ cell $\mathrm{FP}_{\mathrm{L} 1}$ recombinant at $37^{\circ} \mathrm{C}$ for $1 \mathrm{~h}$. After a 6 -h incubation at $37^{\circ} \mathrm{C}$ in DMEM supplemented with $2 \%$ foetal calf serum and $\mathrm{P} / \mathrm{S}$, the cells were washed twice with $\mathrm{PBS}^{-}$, fixed with $2 \%$ paraformaldehyde (Polysciences) in $\mathrm{PBS}^{-}$for $10 \mathrm{~min}$ at room temperature, followed by $100 \%$ cold acetone for $5 \mathrm{~min}$ at $4^{\circ}$ C. The samples were incubated with either monoclonal CamVir-1 (BD Biosciences, 1:100) or mouse (C. Giorgi, $1: 50$ ) or rabbit (R20, from our laboratory, 1:500) polyclonal anti-HPV-L1 antibodies, followed by a 1:100 FITC antiserum (Cappel, MP Biomedicals, Inc., Aurora, OH, USA). The R20 antibodies were obtained by multiple inoculations of one rabbit with the $\mathrm{FP}_{\mathrm{L} 1}$ recombinant. Before use, serum from R20 was immmunoadsorbed overnight with FPwt-infected Vero cells to remove antibodies raised against the vector. FPwt-infected Vero cells were used as a negative control, while CaSki and HeLa cells were used as positive controls. Samples were viewed under a Zeiss Axioskop fluorescence microscope.

\section{Transmission electron microscopy}

Confluent Vero, MRC-5, and CEFs cells were infected with the $\mathrm{FP}_{\mathrm{L} 1}$ recombinant and FPwt at $5 \mathrm{PFU} /$ cell for 1 $\mathrm{h}$ at $37^{\circ} \mathrm{C}$. On days 1 and 3 p.i., the cells were harvested for transmission electron microscopy (TEM). After centrifugation at $1,000 \times g$ for $10 \mathrm{~min}$ at room temperature, the cells were fixed in $2.5 \%$ glutaraldehyde (Polysciences) in $0.1 \mathrm{M} \mathrm{Na}$ cacodylate buffer, $\mathrm{pH} 7.4$, for $1 \mathrm{~h}$ at $4^{\circ} \mathrm{C}$. They were then rinsed twice, and post-fixed in cacodylate-buffered $1 \% \mathrm{OsO}_{4}$ at $4^{\circ} \mathrm{C}$ for $1 \mathrm{~h}$. The specimens were dehydrated through a series of graded ethanol solutions and propylene oxide, and embedded in Poly/Bed 812 resin mixture. Ultrathin sections were obtained using a Sorvall MT2B ultramicrotome equipped with a diamond knife, and they were stained with water-saturated uranyl acetate and $0.4 \%$ lead citrate in $0.1 \mathrm{M} \mathrm{NaOH}$. VLPs from the commercial HPV Gardasil $^{\circledR}$ vaccine were negative-stained with water-saturated uranyl-acetate and used as a control. The specimens were viewed with a Philips CM10 electron microscope.

\section{Real-time PCR}

RNA was extracted from Vero cells infected with 2 $\mathrm{PFU} /$ cell $\mathrm{FP}_{\mathrm{L} 1}$ recombinant, and harvested on days 1, 2, 7, 10, 14, 18 and 22 p.i.. The cells were rinsed twice with $\mathrm{PBS}^{-}$, scraped from the Petri dishes with a rubber policeman, and centrifuged at $1,500 \times g$ for $5 \mathrm{~min}$. After lysis, the RNAs were extracted using the RNeasy mini kit (Invitrogen, Carlsbad, CA, USA), according to the 
manufacturer instructions. Reverse-transcriptase reactions were performed in a final volume of $50 \mu \mathrm{l}$, using 3 $\mu \mathrm{g}$ RNA and the High Capacity cDNA Archive kit (PE Applied Biosystems, Foster City, CA, USA). The reactions were performed at $25^{\circ} \mathrm{C}$ for $10 \mathrm{~min}$, followed by $48^{\circ} \mathrm{C}$ for $30 \mathrm{~min}$, and $95^{\circ} \mathrm{C}$ for $5 \mathrm{~min}$. The cDNA $(5 \mu \mathrm{l})$ was then added to each well of a MicroAmp Optical 96well reaction plate (Applera, PE Applied Biosystems) in the presence of $2 \times$ Power SYBRA green master mix, and forward V392 (5'-GGA-GTA-CGA-CCT-GCA-GTTCAT-CT-3') and reverse V393 (5'-CTG-CGT-TCATCG-TGT-GGA-TGT-3') primers to identify the HPVL1 gene, in a final volume of $25 \mu \mathrm{l}$. The primers V385 (5'-AGC-AAA-GAC-CCC-AAC-GAG-AA-3') and V386 (5'-GGC-GGC-GGT-CAC-GAA-3') were used for the GFP gene, V380 (5'-TGG-AGA-TGA-ACT-CGG-ACCTC-3') and V381 (5'-CGA-CCA-CCA-CCA-ACT-TCAA-3') for the housekeeping RPS7 human gene. FPwtinfected Vero cells and Vero cells transfected for $24 \mathrm{~h}$ with the pUF3/HPV-L1 plasmid (kindly supplied by M. Mueller, German Cancer Research Centre, Heidelberg, Germany) or the pEGFP plasmid were used as negative and positive controls, respectively. All of the reactions were performed in an ABI PRISM 7700 apparatus (PE Applied Biosystems). The PCR conditions were $50^{\circ} \mathrm{C}$ for $2 \mathrm{~min}, 95^{\circ} \mathrm{C}$ for $15 \mathrm{~min}$, followed by 40 cycles at $95^{\circ} \mathrm{C}$ for $15 \mathrm{~s}$ and $60^{\circ} \mathrm{C}$ for $1 \mathrm{~min}$. A 20-min dissociation protocol was also applied. Two different analyses were performed and the copy numbers of the HPV-L1 and GFP transcripts were calculated using the comparative $C_{t}$

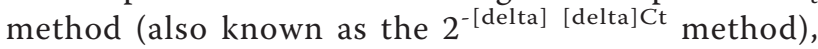
where [delta] $C_{t}$, sample $=C_{t, L 1}-C_{t}$, RPS7, [delta] $C_{t}$, sample is the $C_{t}$ value for any sample normalised to the RPS7 endogenous housekeeping transcripts and [delta] [delta] $C_{t}=[$ delta $] C_{t}$, sample $-[$ delta $] C_{t}$, wt. In all of the samples, the $2^{-[\text {delta] [delta]Ct }}$ refers to an N-fold increase of HPVL1/GFP copy number relative to the control.

\section{Results}

$\mathrm{FP}_{\mathrm{L} 1}$ recombinant expresses the mRNA up to day 21 p.i. in non-permissive mammalian cells

The expression of the HPV-L1 transgene after infection by the $\mathrm{FP}_{\mathrm{L} 1}$ recombinant was tested over time by $\mathrm{RT}-\mathrm{PCR}$. The mRNA isolated from infected Vero cells showed that the gene carried by the $\mathrm{FP}_{\mathrm{L} 1}$ recombinant amplified as a band of 530 bp (Figure 1). In particular, HPV-L1 transgene expression was detectable from 3 days p.i., and extended up to day 21 p.i.. The expression levels were determined by densitometric analysis, and they showed that a very high level of expression was maintained up to day 9 p.i., which then constantly decreased. The similar levels of amplification of $\beta$-actin RNA (518 bp) over time confirmed the reliability of these differences in HPV-L1 expression. Mock-infected cells were always negative, as

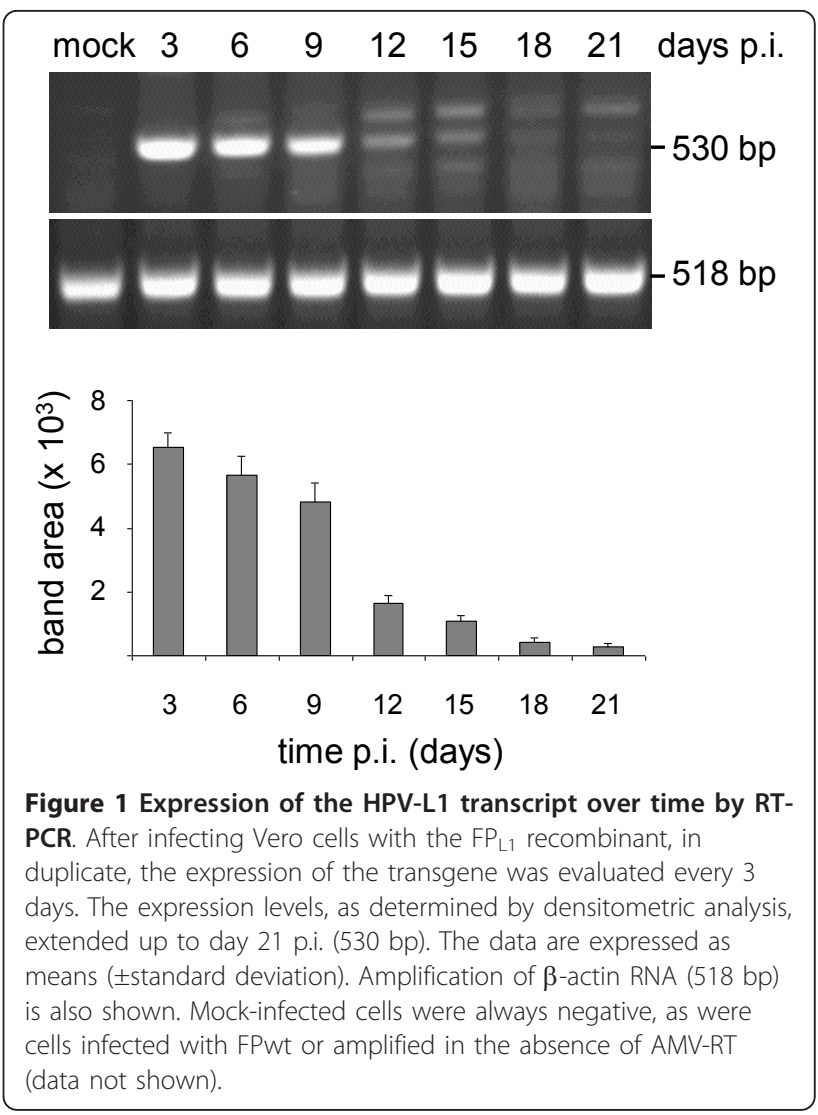

were cells infected with FPwt and those amplified in the absence of AMV-RT (data not shown).

HPV-L1 is expressed in mammalian cells, although at low levels

To determine whether HPV-L1 transcripts were followed by the synthesis of the corresponding viral proteins, immunoprecipitation was performed on Vero, MRC-5, and CEFs cells (Figure 2A). HPV-L1 was detected only in MRC-5 cells (Figure 2A, lane 6), using either monoclonal or rabbit polyclonal antibodies. In the $\mathrm{FP}_{\mathrm{L} 1}$-infected Vero cells, protein expression was not detectable (Figure 2A, lane 3) as well as in CEFs (data not shown), and in mock-infected (Figure 2A, lanes 1 and 4) and FPwt-infected (Figure 2A, lanes 2 and 5) cells. These data prompted us to confirm these results by Western blotting with the same cell lines (Figure 2B). The results showed expression of HPV-L1 not only in MRC-5 cells (Figure 2B, lane 5) but also in Vero cells infected by the $\mathrm{FP}_{\mathrm{L} 1}$ recombinant (Figure $2 \mathrm{~B}$, lanes 2, 55-58 $\mathrm{kDa}$ ). The densitometric analysis of the Western blotting bands of the $\mathrm{L} 1$ protein produced by the $\mathrm{FP}_{\mathrm{L} 1}$ recombinant was compared to the band of a known amount of purified L1 protein used as a standard; this showed that $10^{7}$ Vero and MRC- 5 cells produced $42 \mathrm{ng}$ and $52 \mathrm{ng}$ of protein, respectively. HPV- 

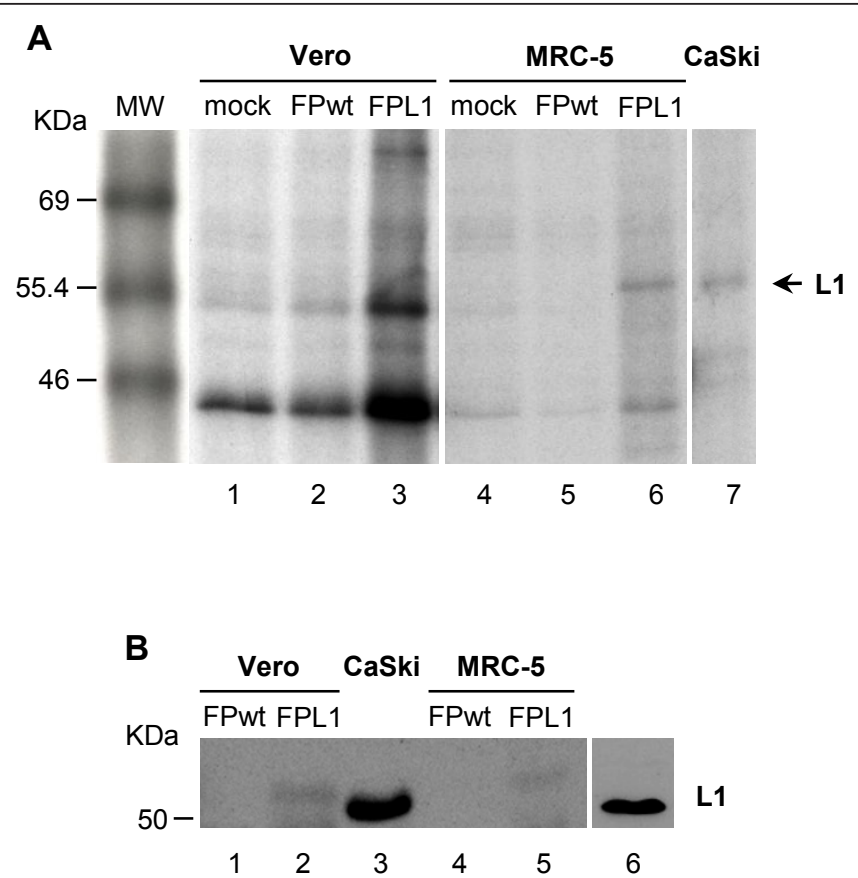

Figure 2 Transcript expression by immunoprecipitation (A) and Western blotting (B). HPV-L1 expression was tested in cells infected with 5 PFU/cell of the $F_{L 1}$ recombinant virus. By immunoprecipitation, HPV-L1 was detected only in MRC-5 cells (A, lane 6), whereas by Western blotting HPV-L1 expression was seen not only in MRC-5 cells (B, lane 5), but also in Vero cells (B, lane 2). Both immunoprecipitation and Western blotting were performed using the CamVir-1 monoclonal antibody. HPV-L1 produced by an engineered bacterial vector was used as a molecular weight marker (lane 6) and CaSki cells as a positive control (lane 3). No specific proteins were seen in mock-infected (A, lanes 1,4$)$ and FPwtinfected (A, lanes 2, 5; B, lanes 1,4) cells or in replication-permissive CEFs (data not shown). HPV-L1 (B, lane 6) and CaSki cells (A, lane 7; B, lane 3), used as positive controls, also showed a clear 55-kDa band.

L1 produced by an engineered bacterial vector was used as a molecular-weight marker (Figure 2B, lane 6) and CaSki cells as a positive control (Figure 2B, lane $3)$. No specific bands were seen when Vero cells were infected with FPwt (Figure 2B, lanes 1 and 4) or in replication-permissive CEFs (data not shown). It is worth noting that although different monoclonal and polyclonal antibodies were used to determine the expression of HPV-L1, only the monoclonal BD antibody showed specificity and high avidity in all of the different tests.

\section{Immunofluorescence results}

To determine the localisation of HPV-L1, immunofluorescence (Figure 3) was performed on Vero, MRC-5, and CEFs cells infected with the $\mathrm{FP}_{\mathrm{L} 1}$ recombinant. In all these different cell types, which were either non-permissive (Vero and MRC-5, Figure 3, 1b, 2b) or permissive (CEFs, Figure $3 \mathrm{~b}$ ) for replication, immunofluorescence was detected at the nuclear level using monoclonal or polyclonal antibodies. No fluorescence was seen in the respective different cell types infected with FPwt (Figure 3, 1a, 2a, 3a). As expected, CaSki and HeLa cells used as positive controls showed clear nuclear immunofluorescence (data not shown).

\section{Only limited amounts of VLPs are found in Vero and MRC- 5 cells}

Structural capsid proteins can self-assemble into VLPs spontaneously. Non-permissive Vero (Figure 4A) and MRC-5 (Figure 4B) cells, as well as permissive CEFs (not shown), were infected with the $\mathrm{FP}_{\mathrm{L} 1}$ recombinant, and VLP formation was examined at the ultrastructural level by electron microscopy. In both Vero and MRC-5 cells, $\mathrm{FP}_{\mathrm{L} 1}$ recombinant virions were seen attached to the cell membrane (data not shown). Complete VLPs (T7, 72 pentamers) were seen in Vero cells at different times p.i., although in limited amounts and mainly enclosed in pseudo-vacuoles (Figure 4A). These pseudovacuoles seem to be the result of tangential sections of invaginations of the cell membrane, as shown by the unstructured background characteristics of the extracellular environment. In MRC-5 cells, only unassembled particles (T1, 12 pentamers) were seen in the nucleus (Figure $4 \mathrm{~B}$ ), whereas they could not be detected in $\mathrm{FP}_{\mathrm{L1}}$ infected CEFs (data not shown). 

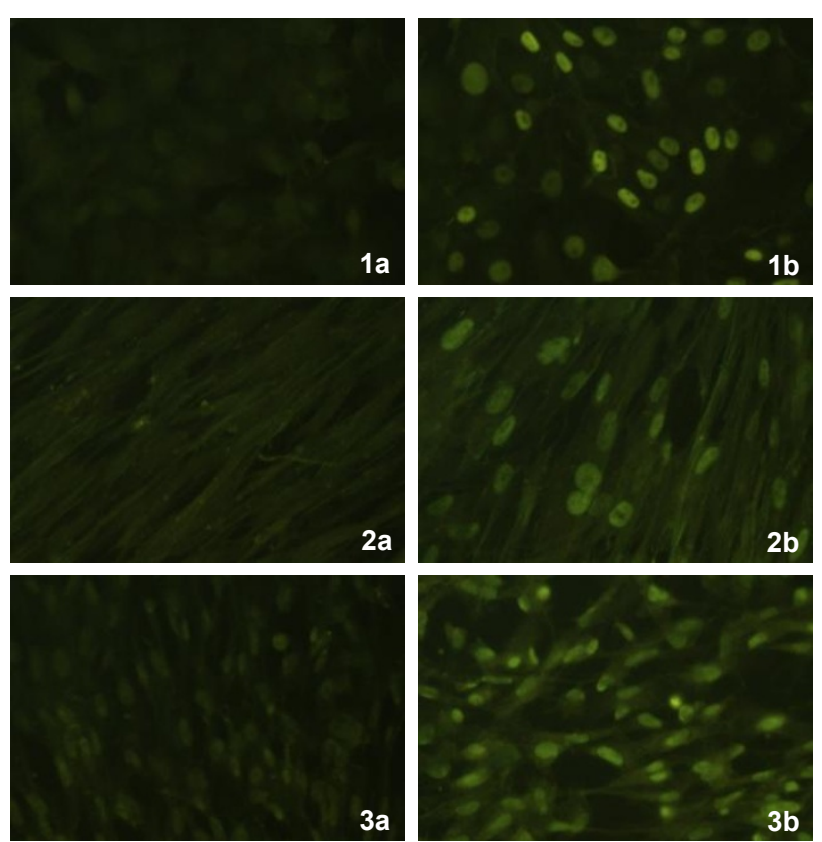

Figure 3 Heterologous protein expression by immunofluorescence. In all the different, either non-permissive (Vero and MRC-5 cells, 1b, 2b) or permissive (CEFs, 3b) cell types, immunofluorescence was detected at the nuclear level, using the CamVir-1 antibody. No fluorescence was seen in the respective different cell types infected with FPwt (1a, 2a, 3a). As expected, the CaSki and HeLa cells used as positive controls showed clear nuclear immunofluorescence (data not shown).

\section{GFP is well expressed over time}

To determine whether the limited amount of VLPs can be ascribed to the interaction of the HPV-L1 and GFP genes driven by the VVH6 and SP promoters, respectively, a quantitative comparison between the HPV-L1 and GFP transcripts was performed over 3 weeks by real-time PCR at different days p.i. (Figure 5). The GFP mRNAs were expressed over time at a good level as well as the HPV-L1 transcripts, reaching their maximum expression level on day 7 p.i..

\section{Discussion}

HPV-16 infection is the major risk factor for the development of cervical neoplasia and invasive cancer [38], and its evidence as the primary aetiologic agent of cervical cancer has been shown across a wide variety of epidemiologic and experimental studies [39]. The expression of the major L1 capsid protein of papillomavirus (HPV-L1) leads to self-assembly of VLPs, that display conformational epitopes recognised by neutralizing monoclonal antibodies [40], as has been demonstrated using baculovirus-transduced insect cells $[41,42]$ or yeast [43-45]. The preventive VLP-based vaccines, that have been recently developed (Gardasil ${ }^{\circledR}$, Merck; Cervarix $^{\circledR}$, Glaxo SmithKline Biologicals) and approved for immunisation programmes in several countries [46], are effective in eliciting protective immunity through induction of a prominent humoral response $[6,13,14,47]$.
However, their cost is unaffordable by the healthcare systems of less-developed countries, where the incidence of HPV-associated disease is extremely high, and the vaccine is most needed, also because HIV-positive subjects are unable to clear HPV infections. Also, as seen for non-replicating vaccines, VLPs are endocytosed by antigen-presenting cells, mainly presented to $\mathrm{CD}^{+}{ }^{+} \mathrm{T}$ lymphocytes in association with MHC class II molecules, and require boost inoculations to maintain high antibody levels and immune cell memory. Recombinant live viral vaccines driving HPV transgene expression represent an attractive alternative as they might induce humoral and cellular immune responses and a long-lasting immunity without the need for numerous recalls.

In the present study, we have described the construction, transcription and protein expression of a new FP recombinant containing the humanised L1 gene of HPV16, and we have demonstrated that: (1) HPV-L1 is correctly expressed in mammalian cells, as demonstrated by RT-PCR, immunoprecipitation, Western blotting, and real-time PCR; (2) in spite of the abortive replication of the FP virus vector in mammalian cells, the transcription of HPV-L1 is long lasting; (3) HPV-L1 is localised at the nuclear level, as seen by immunofluorescence; (4) L1 selfassembles both as T1 particles and as VLPs, and it can be found both in non-human and human primate cells.

The long-lasting expression of the HPV-L1 transcripts in mammalian cells confirms the possibility for a non- 


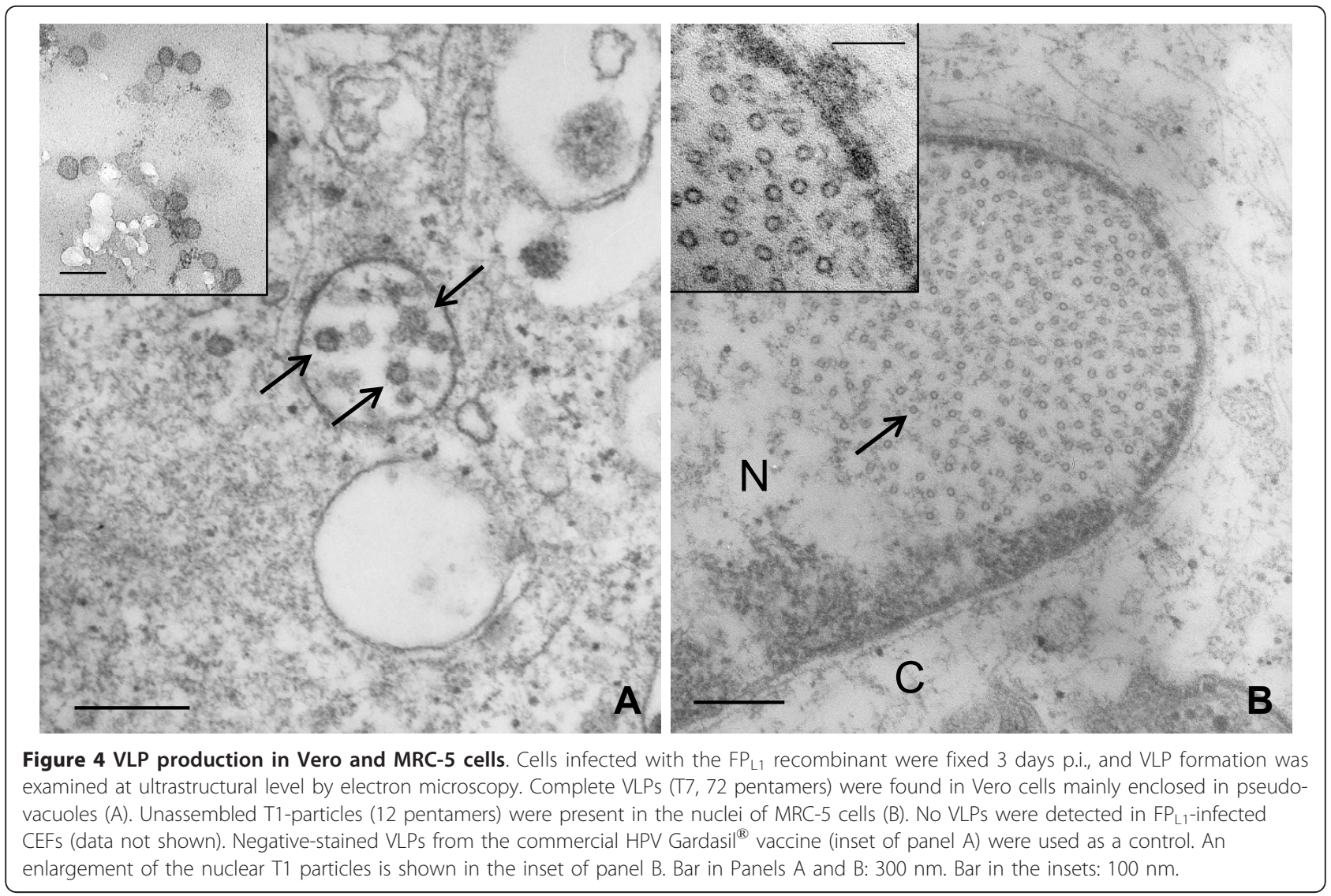

replicating recombinant vector to induce a good immune response [48]. As the HPV-L1 was found by all of the assays in MRC- 5 but not in CEFs cells, we have hypothesised that HPV-L1 expression was mainly limited to human cells due to the humanised HPV-L1 gene sequence that was used for the $\mathrm{FP}_{\mathrm{L} 1}$ recombinant construction. However, detection of HPV-L1 also in non-human primate Vero cells by Western blotting instead suggests that although present, only the nonnative HPV-L1 structure can be detected in these cells. The absence of any specific band in $\mathrm{FP}_{\mathrm{L} 1}$-infected CEFs both by immunoprecipitation and Western blotting can

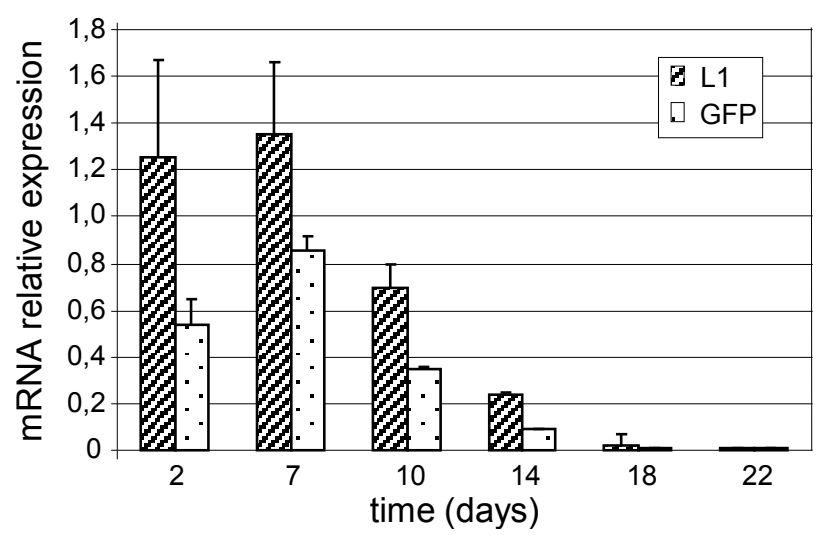

Figure 5 Expression of HPV-L1 and GFP transcripts over time using real-time PCR in restrictive mammalian cells. After infecting Vero cells with 2 PFU/cell of the FP $P_{L 1}$ recombinant, quantitative expression of the HPV-L1 and GFP transgenes was evaluated every 3 days for 22 days. The maximum expression level for both HPV-L1 and GFP were reached on day 7 p.i., and GFP mRNAs were always highly expressed. The copy number of HPV-L1/GFP mRNAs, normalised to the RPS7 endogenous housekeeping transcripts, refers to the N-fold increase vs control mRNA at each time point. The data are expressed as means ( \pm standard deviation) from two independent analyses. 
be ascribed to the prevalent expression of the early and late genes of the vector and to its cytopathogenicity, which might prevent expression of the heterologous HPV-L1 transgene.

On the other hand, the HPV-L1 expression in CEFs determined by immunofluorescence performed $6 \mathrm{~h}$ p.i. demonstrates that HPV-L1 can also be detectable in replication-permissive cells, although only at early times of infection, when the vector is expressing non-structural enzymatic proteins with poor cytopathic effects. Indeed, HPV-L1 expression was sometimes also found in CEFs by immunoprecipitation, when the samples were loaded in excess (our unpublished data). This suggests early/low expression in these cells, which makes it rarely detectable.

Similarly, HPV-L1 capsid proteins never appear to be correctly structured as VLPs in CEFs, although they were present in Vero and MRC-5 cells. While it is not surprising that VLPs are not detectable in cells where the recombinant replicates, as vector protein synthesis might be detrimental to HPV-L1 production and VLP assembly, the reason for the low VLP production in Vero and MRC-5 cells is not completely clear. This cannot be ascribed to the $\mathrm{L} 1$ gene coding sequence inserted into $\mathrm{FP}_{\mathrm{L} 1}$, which, as with other constructs $[31,49,50]$ that can produce VLPs, starts from the second ATG. Indeed, transcription from the first ATG prevents VLP formation (M. Mueller, personal communication).

As already described [51], L1 capsid proteins can selfassemble as single capsomers (pentamers), T1 particles (12 pentamers) or complete VLPs (T7, 72 pentamers). At the ultrastructural level, we demonstrated the presence of both T1 and T7 particles. Although these are present in limited amounts, this confirms that FP-driven L1 proteins can, at least in part, self-assemble correctly. Since the $\mathrm{L} 1$ protein produced by the $\mathrm{FP}_{\mathrm{L} 1}$ recombinant has the NLS, nuclear localization is expected, in spite of the vector transgene expression in the cytoplasm. T1 capsomers were found in the nucleus, which were still not assembled as complete VLPs. VLPs were seen in pseudo-vacuoles, although very rarely, as if they were in the cytoplasm as a result of the tangential section of a plasma membrane invagination. We suggest therefore that the VLPs in the pseudo-vacuoles might represent extracellular VLPs that were previously assembled in the nucleus and were then released by already lysed cells.

We hypothesise that the GFP gene co-inserted with the HPV-L1 transgene into the vector to track the expression of the recombinant, the expression of which is driven by the strong SP synthetic promoter, might interfere with HPV-L1 expression. Although other studies have also used constructs containing GFP for recombinant selection $[31,52]$, the hypothesis that GFP co-espression might hamper high production of the heterologous gene and VLP assembly has already been investigated by K. Kindsmueller (Institute of Medical Microbiology and Hygene, University of Regensburg, Germany, personal communication). By removing the GFP gene, we also obtained higher gene expression using other recombinants produced in our laboratory (unpublished data).

The similar decrease over time in both HPV-L1 and GFP mRNA transcripts shown by real-time PCR does not correlate with the low amounts of VLP production. However, data from our laboratory with recombinants that co-express transgenes and GFP suggest that SP promoter activity and/or GFP expression might interfere negatively, by limiting the synthesis of the L1 protein and VLP assembly. This might justify the good mRNA expression for both of these transgenes up to 10 days $\mathrm{p}$. i. with very low VLP amounts.

It is therefore likely that HPV-L1 protein expression, rather than mRNA, is responsible for the low VLP assembly, which can justify the good mRNA expression for both of these transgenes up to 10 days p.i. with very low VLP amounts.

Therefore, before animal immunization, it will be interesting to compare a new $\mathrm{FP}_{\mathrm{L} 1}$ construct lacking the SP-GFP complex with the present $\mathrm{FP}_{\mathrm{L} 1}$ double recombinant, both for the differences in mRNA and protein expression and for VLP production.

\section{Conclusions}

As L1 appears to be correctly expressed both by replication restrictive and permissive cell lines, the $\mathrm{FP}_{\mathrm{L} 1}$ recombinant might represent a new prophylactic vaccine, which can putatively cross-present the antigen in association with both MHC class I and II complexes. This might contribute to a complete humoral and cellular immunity when compared to the commercially available vaccines. L1 expression was observed for almost three weeks, and this is a pre-requisite for a durable immune response. The limited amounts of assembled VLPs seen by electron microscopy make these data preliminary to the use of a modified construct for the analysis of the immune responses and protection in animal models. Although the currently available vaccines are efficient in eliciting a neutralizing immunity, the 7-year efficacy appears limited since oncogenicity is often revealed only after decades of incubation. An alive nonreplicating vaccine might fit the purpose better if it can produce the L1 protein and VLPs.

\section{Acknowledgements}

This project was supported in part by the Italian Ministry of University and Research (MIUR, Cofin-PRIN 2007). We also thank Dr. Luca Volonté for his excellent electron microscopy contribution, and Dr. Christopher Berrie for editorial assistance with the manuscript. 


\section{Author details}

'Department of Medical Pharmacology, University of Milan, 20129 Milan, Italy. ${ }^{2}$ Department of Pharmacological Sciences, University of Milan, 20133 Milan, Italy. ${ }^{3}$ Cellular and Molecular Pharmacology Section, Institute of Neurosciences, University of Milan, 20129 Milan, Italy.

\section{Authors' contributions}

CZ performed the molecular cloning and RT-PCR, prepared the primary cell cultures, revised the Figures, and analysed the data and the study results; EP performed animal immunisations, Western blotting, real-time PCR, and prepared Figures; SP performed the production of the poxvirus and the HPV-L1 recombinant; MB performed the immunofluorescence assays, and the poxvirus recombinant purification; CDGM performed electron microscopy, and conceptualised, designed, and supervised the whole study; AR performed the immunoprecipitation assays, assisted in the animal immunisations, analysed the data, interpreted the study results, and prepared the manuscript. All of the authors have read and approved the present version of the manuscript.

\section{Competing interests}

The authors declare that they have no competing interests.

Received: 27 July 2011 Accepted: 4 November 2011

Published: 4 November 2011

\section{References}

1. Bosch X, Burchell AN, Schiffman MH, Giuliano AR, de Sanjose S, Bruni L, Tortolero-Luna G, Kjaer SK, Munoz N: Epidemiology and natural history of human PV infections and type-specific implications in cervical neoplasia. Vaccine 2008, 26:K1-K16.

2. Pisani P, Bray F, Parkin DM: Estimates of the world-wide prevalence of cancer for 25 sites in the adult population. Int I Canc 2002, 97:72-81.

3. Parkin DM, Bray F, Ferlay J, Pisani P: Global cancer statistics, 2002. CA Cancer J Clin 2005, 55:74-108.

4. Wilczynski SP, Bergen S, Walker J, Liao SY, Pearlman LF: Human papillomaviruses and cervical cancer: analysis of histopathologic features associated with different viral types. Hum Pathol 1988, 19:697-704.

5. Bosch X, Manos MM, Munoz N, Sherman M, Jansen AM, Peto J, Schiffman MH, Moreno V, Kurman RJ, Shah KV: Prevalence of human papillomavirus in cervical cancer: a worldwide perspective. International biological study on cervical cancer (IBSCC) Study Group. J Natl Cancer Inst 1995, 87:796-802.

6. Palmer KE, Jenson AB, Kouokam JC, Lasnik AB, Ghim SJ: Recombinant vaccines for the prevention of human papillomavirus infection and cervical cancer. Exp Mol Pathol 2009, 86:224-233.

7. Harper DM, Franco EL, Wheeler CM, Moscicki AB, Romanowski B, RoteliMartins CM, Jenkins D, Schuind A, Costa Clemens SA, Dubin G, HPV Vaccine Study group: Sustained efficacy up to 4.5 years of a bivalent L1 virus-like particle vaccine against human papillomavirus types 16 and 18: followup from a randomised control trial. Lancet 2006, 367:1247-1255.

8. FUTURE II Study Group: Prophylactic efficacy of a quadrivalent human papillomavirus (HPV) vaccine in women with virological evidence of HPV infection. J Infect Dis 2007, 196:1431-1432.

9. Joura EA, Kjaer SK, Wheeler CM, Sigurdsson K, Iversen OE, HernandezAvila M, Perez G, Brown DR, Koutsky LA, Tay EH, Garcia P, Ault KA, Garland SM, Leodolter S, Olsson SE, Tang GW, Ferris DG, Paavonen J, Lehtinen M, Steben M, Bosch X, Dillner J, Kurman RJ, Majewski S, Munoz N, Myers ER, Villa LL, Taddeo FJ, Roberts C, Tadesse A, Bryan J, Lupinacci LC, Giacoletti KE, Lu S, Vuocolo S, Hesley TM, Haupt RM, Barr E: HPV antibody levels and clinical efficacy following administration of a prophylactic quadrivalent HPV vaccine. Vaccine 2008, 26:6844-6851.

10. Reisinger KS, Block S, Lazcano-Ponce E, Samakoses R, Esser MT, Erick J, Puchalski D, Giacoletti KE, Sings HL, Lukac S, Alvarez FB, Barr E: Safety and persistent immunogenicity of a quadrivalent human papillomavirus types $6,11,16,18 \mathrm{~L} 1$ virus-like particle vaccine in preadolescents and adolescents: a randomized controlled trial. Pediatr Infect Dis J 2007, 26:201-209.

11. GlaxoSmithKline Vaccine HPV-007 Study Group, Romanowski B, de Borba PC, Naud PS, Roteli-Martins CM, De Carvalho NS, Teixeira JC, Aoki F, Ramjattan B, Shier RM, Somani R, Barbier S, Blatter MM, Chambers C,
Ferris D, Gall SA, Guerra FA, Harper DM, Hedrick JA, Henry DC, Korn AP, Kroll R, Moscicki AB, Rosenfeld WD, Sullivan BJ, Thoming CS, Tyring SK, Wheeler CM, Dubin G, Schuind A, Zahaf T, Greenacre M, Sgriobhadair A: Sustained efficacy and immunogenicity of the human papillomavirus (HPV)-16/18 AS04-adjuvanted vaccine: analysis of a randomised placebocontrolled trial up to 6.4 years. Lancet 2009, 374:1975-1985.

12. Thönes $N$, Herreiner $A$, Schadlich L, Piuko K, Müller M: A direct comparison of human PV type $16 \mathrm{~L} 1$ particles reveals a lower immunogenicity of capsomeres than viruslike particles with respect to the induced antibody response. J Virol 2008, 82:5472-5485.

13. Stanley M: Prospects for new human papillomavirus vaccines. Curr Opin Infect Dis 2010, 23:70-75.

14. Schiller JT, Castellsague X, Villa LL, Hildesheim A: An update of prophylactic human PV L1 virus-like particle vaccine clinical trial results. Vaccine 2011, 26:K53-K61.

15. Chen J, Ni G, Liu XS: Papillomavirus virus like particle-based therapeutic vaccine against human papillomavirus infection related diseases: Immunological problems and future directions. Cell Immunol 2011, 269:5-9.

16. Bellone S, El-Sahwi K, Cocco E, Casagrande F, Cargnelutti M, Palmieri M, Bignotti E, Romani C, Silasi DA, Azodi M, Schwartz PE, Rutherford TJ, Pecorelli S, Santin AD: Human papillomavirus type 16 (HPV-16) virus-like particle L1-specific CD8+ cytotoxic T lymphocytes (CTLs) are equally effective as E7-specific CD8+ CTLs in killing autologous HPV-16-positive tumor cells in cervical cancer patients: implications for L1 dendritic cellbased therapeutic vaccines. J Virol 2009, 83:6779-6789.

17. Di Bonito P, Grasso F, Mochi S, Petrone L, Fanales-Belasio E, Mei A, Cesolini A, Laconi G, Conrad H, Bernhard H, Dembek CJ, Cosma A, Santini SM, Lapenta C, Donati S, Muratori C, Giorgi C, Federico M: Antitumor CD8+ T cell immunity elicited by HIV-1-based virus-like particles incorporating HPV-16 E7 protein. Virology 2009, 395:45-55.

18. Rudolf MP, Fausch SC, Da Silva DM, Kast WM: Human dendritic cells are activated by chimeric human papillomavirus type- 16 virus-like particles and induce epitope-specific human T cell responses in vitro. I Immunol 2001, 166:5917-5924

19. Wyatt LS, Whitehead SS, Venanzi KA, Murphy BR, Moss B: Priming and boosting immunity to respiratory syncytial virus by recombinant replication-defective vaccinia virus MVA. Vaccine 1999, 18:392-397.

20. Picard O, Lebas J, Imbert JC, Bigel P, Zagury D: Complication of intramuscular/subcutaneous immune therapy in severely immunecompromised individuals. J Acquir Immune Defic Syndr 1991, 4:641-643.

21. Lico $C$, Chen $Q$, Santi L: Viral vectors for production of recombinant proteins in plants. J Cell Physiol 2008, 216:366-377.

22. Maclean J, Koekemoer M, Olivier AJ, Stewart D, Hitzeroth II, Rademacher T, Fischer R, Williamson AL, Rybicki EP: Optimization of human papillomavirus type 16(HPV-16) L1 expression in plants: comparison of the suitability of different HPV-16 L1 gene variants and different cellcompartment localization. J Gen Virol 2007, 88:1460-1469.

23. Paz De la Rosa G, Monroy-García A, Mora-García Mde L, Peña CG, Hernández-Montes J, Weiss-Steider B, Gómez-Lim MA: An HPV 16 L1-based chimeric human papilloma virus-like particles containing a string of epitopes produced in plants is able to elicit humoral and cytotoxic T-cell activity in mice. Virol J 2009, 6:2.

24. Taylor J, Paoletti E: Fowlpox virus as a vector in non-avian species. Vaccine 1988, 6:466-468.

25. Baxby D, Paoletti E: Potential use of nonreplicating vectors as recombinant vaccines. Vaccine 1992, 10:8-9.

26. Skinner MA, Laidlaw SM, Eldaghayes I, Kaiser P, Cottingham MG: Fowlpox virus as a recombinant vaccine vector for use in mammals and poultry. Expert Rev Vaccines 2005, 4:63-76.

27. Franchini G, Gurunathan S, Baglyos L, Plotkin S, Tartaglia J: Poxvirus-based vaccine candidates for HIV: two decades of experience with special emphasis on canarypox vectors. Expert Rev Vaccines 2004, 3:S75-S88.

28. Irvine KR, Chamberlain RS, Shulman EP, Rosenberg SA, Restifo NP: Enhancing efficacy of recombinant anticancer vaccines with prime/boost regimens that use two different vectors. J Natl Cancer Inst 1997, 89:1595-1601.

29. Taylor J, Weinberg R, Languet B, Desmettre P, Paoletti E: Recombinant fowlpox virus inducing protective immunity in nonavian species. Vaccine 1988, 6:497-503. 
30. Di Bonito P, Grasso F, Mochi S, Accardi L, Donà MG, Branca M, Costa S, Mariani L, Agarossi A, Ciotti M, Syrjänen K, Giorgi C: Serum antibody response to Human papillomavirus (HPV) infections detected by a novel ELISA technique based on denatured recombinant HPV16 L1, L2, E4, E6 and E7 proteins. Infect Agent Cancer 2006, 1:6-14.

31. Leder C, Kleinschmidt JA, Wiethe C, Müller M: Enhancement of capsid gene expression: preparing the human papillomavirus type 16 major structural gene L1 for DNA vaccination purposes. J Virol 2001, 75:9201-9209.

32. Rosel JL, Earl PL, Weir J, Moss B: Conserved TAAATG Sequence at the Transcriptional and Translational Initiation Sites of Vaccinia Virus Late Genes Deduced by Structural and Functional Analysis of the Hindlll H Genome Fragment. J Virol 1986, 60:436-449.

33. Radaelli A, Zanotto C, Perletti G, Elli V, Vicenzi E, Poli G, De Giuli Morghen C: Comparative analysis of immune responses and cytokine profiles elicited in rabbits by the combined use of recombinant fowlpox viruses, plasmid and virus-like particles in prime-boost vaccination protocols against SHIV. Vaccine 2003, 21:2052-2064

34. Chakrabarti S, Sisler JR, Moss B: Compact, synthetic, vaccinia virus early/ late promoter for protein expression. Biotechniques 1997, 23:1094-1097.

35. Radaelli A, De Giuli Morghen C: Expression of HIV-1 envelope gene by recombinant avipoxvirus. Vaccine 1994, 12:1101-1109.

36. Parks RJ, Krell PJ, Derbyshire JB, Nagy E: Studies of fowlpox virus recombination in the generation of recombinant vaccines. Virus Res 1994, 32:283-297.

37. Rasband WS: U.S. National Institutes of Health, Bethesda, Maryland, USA. 2009 [http://rsb.info.nih.gov/ij/].

38. zur Hausen $\mathrm{H}$ : Papillomavirus infections-a major cause of human cancers. Biochim Biophys Acta 1996, 1288:F55-F78.

39. Walboomers JM, Jacobs MV, Manos MM, Bosch X, Kummer JA, Shah KV, Snjders PJ, Peto J, Meijer CJ, Munoz N: Human papillomavirus is a necessary cause of invasive cervical cancer worldwide. J Pathol 1999, 189:12-19.

40. Ghim SJ, Jenson AB, Schlegel R: HPV-1 L1 protein expressed in cos cells displays conformational epitopes found on intact virions. Virology 1992, 190:548-552.

41. Kirnbauer R, Booy N, Chengt DR, Lowy DR, Schiller JT: Papillomavirus Li major capsid protein self-assembles into virus-like particles that are highly immunogenic. Proc Natl Acad Sci USA 1992, 89:12180-12184.

42. Rose RC, Bonnez W, Reichman RC, Garcea RL: Expression of human PV type 11 L1 protein in insect cells: in vivo and in vitro assembly of viruslike particles. J Virol 1993, 67:1936-1944.

43. Jansen KU, Rosolowsky M, Schultz LD, Markus HZ, Cook JC, Donnelly JJ, Martinez D, Ellis RW, Shaw AR: Vaccination with yeast-expressed cottontail rabbit papillomavirus (CRPV) virus-like particles protects rabbits from CRPV-induced papilloma formation. Vaccine 1995, 13:1509-1514.

44. Patel MC, Patkar KK, Basu A, Mohandas KM, Mukhopadhyaya R: Production of immunogenic human papillomavirus-16 major capsid protein derived virus like particles. Indian J Med Res 2009, 130:213-218.

45. Hofmann KJ, Cook JC, Joyce JG, Brown DR, Schultz LD, George HA, Rosolowsky M, Fife $\mathrm{KH}$, Jansen KU: Sequence determination of human PV type $6 \mathrm{a}$ and assembly of virus-like particles in Saccharomyces cerevisiae. Virology 1995, 209:506-518.

46. Koutsky LA, Harper DM: Chapter 13: Current findings from prophylactic HPV vaccine trials. Vaccine 2006, 24:S114-S121.

47. Stanley M, Gissmann L, Nardelli-Haefliger D: Immunobiology of human PV infection and vaccination-implications for second generation vaccines. Vaccine 2008, 26:K62-K67.

48. Zanotto C, Pozzi E, Pacchioni S, Volonté L, De Giuli Morghen C, Radaelli A: Canarypox and fowlpox viruses as recombinant vaccine vectors: a biological and immunological comparison. Antiviral Res 2010, 88:53-63.

49. Kirnbauer R, Taub J, Greenstone HL, Roden R, Dürst M, Gissmann L, Lowy DR, Schiller JT: Efficient self-assembly of human papillomavirus type 16 L1 and L1-L2 into virus-like particles. J Virol 1993, 67:6929-6936.

50. Chen XS, Garcea RL, Goldberg I, Casini G, Harrison SC: Structure of small virus-like particles assembled from the L1 protein of human papillomavirus 16. Mol Cell 2000, 5:557-567.

51. Thönes N, Müller M: Oral immunization with different assembly forms of the HPV 16 major capsid protein L1 induces neutralizing antibodies and cytotoxic T-lymphocytes. Virology 2007, 369:375-388.
52. Popov S, Mirshahidi S, Essono S, Song R, Wang X, Ruprecht RM: Generation of recombinant vaccinia viruses via green fluorescent protein selection. DNA Cell Biol 2009, 28:103-108.

doi:10.1186/1479-5876-9-190

Cite this article as: Zanotto et al:: Construction and characterisation of a recombinant fowlpox virus that expresses the human papilloma virus L1 protein. Journal of Translational Medicine 2011 9:190.

\section{Submit your next manuscript to BioMed Central and take full advantage of:}

- Convenient online submission

- Thorough peer review

- No space constraints or color figure charges

- Immediate publication on acceptance

- Inclusion in PubMed, CAS, Scopus and Google Scholar

- Research which is freely available for redistribution

Submit your manuscript at www.biomedcentral.com/submit
C) Biomed Central 